\title{
PERCEIVED FACTORS KEEPING STUDENTS IN OR AWAY FROM DOING SPORTS AND PHYSICAL ACTIVITIES IN TAIWAN REGION ${ }^{i}$
}

\author{
Ngangbam, Shantikumar Meetei ${ }^{i i}$, \\ Chen Jung-Sheng \\ Applied English and Foreign Languages Department, \\ Hungkuo Delin University of Technology, \\ Tucheng, New Taipei City,
} Taiwan

\begin{abstract}
:
In the last six or so decades, researchers have investigated, proved and shown the benefits of sports and physical activities on students' physical and mental health, academic performance and overall personal development. However, many researchers found that more and more students were staying away from sports and physical activities. Today, more than $80 \%$ of adolescent and $40-50 \%$ of college students globally did not meet the current physical activity per day recommended by the World Health Organization, thus keeping them unhealthy and unfit. This led researchers around the world to investigate the perceived facilitators and barriers that keep students away from these healthy activities. But, so far Taiwan region is concerned, no internationally published study has been done on this topic. To fill up the gap, the present quantitative, descriptive crosssectional study investigated what perceived benefits and barriers keep in or away Taiwanese students from doing sports and physical activities. 9 self-designed multiplechoice paper survey questionnaires were administered among 199 students of different age groups, studying at different class levels at three educational institutes in New Taipei City, Taiwan during the six months, April to October, 2021. The collected data was then analyzed using Microsoft Excel Pivot table. Results: $82 \%$ of students knew doing physical activities could keep them physically and mentally healthy, but only $28 \%$ did enough exercise. Main responsible factors were: too much school works, part-time jobs, not enough social encouragements, lack of interest, no self-confidence in sports, and lack of knowledge respectively.
\end{abstract}

最近六年或者說幾十年來，研究人員經由調查，求證，展示出運動競技和體能活動對於 學生們的身心健康、學業成績和全人發展的助益。但是, 許多研究人員也發現，有愈來 
愈多的學生選擇了疏遠運動競賽和體能活動。今日全球有超過 $80 \%$ 的青少年和 $40-50 \%$ 的 大學生並沒有達到世界衛生組織當前每日體育的訓練量，導致他們不健康和不良的體態。 世界各地的研究人員想要利用調研，找出學生保持或遠離運動與體能活動所感知的有利 的與障礙因素。但是, 有關於台灣地區, 目前國際上還沒有發表過相關研究。為了填補 這一空白, 目前的定量、描述性橫斷面研究調查了台灣學生進行運動競技和體能活動所 感知的好處和障礙因素。 2021 年 4 月至 10 月的六個月期間，筆者在新北市三所教育機構 的不同班級學習的 199 名不同年齡組學生中進行了自行設計的 9 題複選的問卷調查。然後 對收集的數據進行了分析使用 Microsoft Excel 數據透視表。結果 有 $82 \%$ 的學生知道從事 體能鍛煉可以保持身心健康，卻只有 $28 \%$ 學生的訓練是足夠的，其主要因素分別為：學 校作業過多、兼職工作過多、社會鼓勵不足、缺乏興趣、對運動缺乏自信、知識嘈乏。

Keywords: sports, physical activities, facilitators and barriers, health, and academic performance

關鍵詞：運動競技、體能活動、促進因素和障礙、健康和學業成績

\section{Introduction}

\subsection{Background and Literature Review}

In the last six decades or so, many researchers, scholars and experts have investigated and published many research papers, articles, theses and dissertations on the correlation between education and sports and physical activities, the impact and benefits sports and physical activities offer on students' physical health, mental health, as well as on academic achievements. In spite of all these research findings and benefits offered, on the contrary, the number of students involving in sports and physical activities is decreasing significantly day by day. One study published in The Lancet Child \& Adolescent Health journal produced by researchers from the World Health Organization, finds that more than $80 \%$ of school-going adolescents globally did not meet current recommendations of at least one hour of physical activity per day. This finding was based on the study conducted during 2001-2016, and reported by 1.6 million 11 to 17-year-old students across 146 countries around the world (The Lancet Child \& Adolescent Health, 2021). So, many researchers around the world have investigated what keeps in or away students away from doing these healthy physical activities.

But, so far Taiwan is concerned, no internationally published study has been done on this topic. Thus, the main purpose of this study is to investigate and find out what facilitators keep in or barriers keep away these students from doing sports and physical activities, and discover the ways to encourage them to involve in these healthy activities to keep them physically and mentally healthy, which will eventually lead them to achieving better academic achievement, and success in life in the long run.

To paraphrase Gorton (2010), since the publication of James Coleman's classic The Adolescent Society (1961), a large number of researchers like Eidsmoe (1961), Edwards 
(1967), Rehberg \& Schaefer (1968), Schafer \& Armer (1968), Spady (1970), Hanks \& Eckland (1976), Otto \& Duane (1977), Landers \& Landers (1978) have been inspired and many further researches have been done and published on the impact of sports on academic achievement.

The inspiring train continued. In their research literature review, Tomporowski, Davis, Miller, and Naglieri's (2008) stated that systematic exercise programs may actually enhance the development of specific types of mental processing known to be important for meeting challenges encountered both in academics and throughout the lifespan. Mohammad, Asif, Umar \& Uzma (2012) found that there is a link between participation in sports and academic performance. They found sports activities had positive influence by enhancing memory, academic focus, concentration, improving grades, and ability to succeed academically.

In his study for Master's thesis, Prasad (2012) compared two groups of students from decile 1 and decile 2 schools. It was found that students who participate in sports generally do better than those who do not. His support for this statement lied in the number of students who reported playing a sport compared with those reported with no sport involvement. Prasad stated that in school 1, of the 52 students who participated in the study, $83 \%$ of the students were sports participants compared to school 2's $68 \%$ of 34 students.

On their review on literature, Michael, Merlo, Basch, Wentzel, \& Wechsler (2015) summarized and highlighted the critical connection between health and academic achievement. They stated that the evidence in their literature review supports the need for school health services by demonstrating the association between chronic conditions and decreased achievement. Donnelly et al. (2016) also found the evidence to suggest that there are positive associations among physical education, fitness, cognition, and academic achievement. Based on the evidence available, they concluded that physical education has a positive influence on cognition as well as brain structure and function.

Not only physical activities improve academic achievement, Andersen et al.'s (2017) study revealed that there is a positive effect of physical fitness even on attendance in post-compulsory education by establishing the relation between physical fitness, academic achievement and post-compulsory education commencement, concluding that physical fitness helped more students to attend higher study.

In a two-year, with three-time points longitudinal study of five public junior high schools in two suburban municipalities in Okinawa prefecture, Japan from April 2015 to July 2017, Kyan, Takakura, \& Miyagi (2018) detected a possibility that an increase in physical fitness leading to good academic achievement among junior high school boys, regardless of between-person differences of physical level.

In a two-semester study in a Shanghai high school to examine the effect of a strengthened physical education pilot program consisting of specialized sports training on students' academic performance in the high school context, Zhang, Ma, Zhao, Shen, \& Jiang (2019) found that strengthened physical education had a significantly positive 
effect on overall academic performance among the high school students, especially in Chinese language and English language scores.

In his qualitative-longitudinal case study of a high school student for two semesters to investigate the impact of exercise, sports participation and physical activities on academic performance, Ngangbam (2020, not published yet) found a very significant change on the part of the studied subject. Not only changed in his attitude from indifference to seriousness in the class, it was found that the subject of study also improved his score from $80 \%$ to $95 \%$ in his English test.

Recently, in their longitudinal study of 7, 11 and 14 year old students, Vasilopoulos, \& Ellefson (2021) examined the relationship amongst physical activity, selfregulation in a multi-dimensional approach and educational outcomes. They found out that emotional regulation was linked to physical activity in early childhood to subsequently affect academic achievement. Not only sports and physical activities improve students' physical health and mental health, it also directly influences social cognition, the processes by which people draw inferences about other people's belief and intentions, and how people weigh social situational factors in making these inferences (Lopez, Vera, Lopez V., Jaramillo, 2020).

In spite of all these studies, proofs, and benefits sports and physical activities offer to student community, studies consistently show that physical activity have been declining day by day sharply among students. The decline in physical activity during adolescence is a key public health concern today. Declines are reported with both selfreport, and objective measures of physical activity. Similarly, declines are documented in cross-sectional, and longitudinal studies. According to Kenneth, Edward, John, Daria \& Hyacinth (2007), age-related declines in physical activity are reported in several countries, including the USA, Canada, Finland, and in Amsterdam.

Considering the declining trend in the adolescent and adulthood, Crumbley, Ledoux, and Johnston (2019) talked about the importance of instilling a habit of doing physical activities during childhood. They stated that as physical activity and sedentary behaviors are developed during the early childhood period, for physical activity to occur in children, parents should also be engaged in and model the physical activity behaviors, increasing the likelihood of young children learning to be physically active.

Seeing the declining trend in physical activity level, many researchers started to investigate the facilitators and barriers, the responsible factors which either help students to stay in or away from doing sports and physical activities. In the past decades, researchers in many countries, especially in the USA, Canada, Europe and some countries of Asian continent have already done researches and investigations on why larger part of student community stay in or away from doing sports and physical activities, found out the factors, and published in public domain. From the research results, it is found that every country has its own responsible benefits and barriers depending on the sociocultural and socio-economic background, demographic structure and other factors. Some factors were found quite common while other factors were unique and different from country to country. 
The influencers which keep students in or away from doing sports and physical activities can be divided into two categories as internal and external influencers. In their study at Baskent University Faculty of Health Sciences in Turky, Arzu, Tuzun, \& Eker (2006) found that lack of time due to busy lesson schedule, parents' giving priority on academic success over exercise, and lack of time due to responsibilities related to the family and social environment were the important external factors for university students staying away from sports and physical activities.

A study investigated by Manuel, Antonio and Antonio (2010) in the University of Almeria (Spain) found that the main barriers were lack of time and lack of social support as for external barriers while not liking the physical activity, not seeing its practicality or usefulness, feeling lazy or with apathy, or thinking that they were not competent in this type of activities were the internal barriers. In their study, Rodolfo, Anna and Oscar (2014) also found that among Spanish university students, too much work and lack of time for exercise were the two highest external barrier factors while fatigue - laziness has been the most highlighted internal barriers.

Regarding internal barriers, in one study in Musket, Oman by Youssef, Shafie, AlMukhaini and Al-Balushi (2013), it was found that substantial proportions of students expressed other recreational activities were more entertaining than exercising $(72.2 \%)$, having limited energy to exercise $(43.3 \%)$ and thinking that exercise was difficult and too tiring (40.1\%). Only $18.0 \%$ were not thinking that exercise has positive health effects. As for external barriers, a high proportion of students agreed that parents give priority to academic success $(71.5 \%)$ or that they lacked leisure time due to academic responsibilities (65.4\%). Other perceived external barriers were lack of exercise equipment in the home $(53.5 \%)$ and lack of leisure time because of social and family responsibilities (39.6\%).

In their study in western part of Saudi Arabia, Awadalla, Aboelyazed, Hassanein, Khalil, Aftab, Gaballa, and Mahfouz (2014) stated that the significant barriers among physically inactive students were: time limitations as the biggest factor $(51.3 \%)$ followed by lack of accessible and suitable sports places (31.1\%), other important priorities (28.1\%), lack of friends to encourage $(27.8 \%)$, lack of support and encouragement from others (23.2\%); lack of safe sporting places $(22.8 \%)$, high cost $(17.7 \%)$ as the external factors while lack of motivation (19.6\%), not being interested in sports (18.5\%), lack of sports skills $(17.8 \%)$, and feeling tired on physical activity $(15.8 \%)$ as the internal barriers.

Smetaniuk, T. et al. (2017) explored the physical activities and sedentary behavior of Canadian Master of Physical Therapy university students as well as the associated facilitators and barriers. In their study, they explored a full $74 \%$ of participants did not meet the recommended physical activity guidelines. Barriers to physical activity included academic pressure to perform, inconsistent and interrupted scheduling due to clinical placements outside their university community, limited time, fatigue, classroom design, and weather. Besides these barriers, the Master Physical Therapy students also identified facilitators which could help them do physical activities, like social supports, purchasing memberships to instill a sense of obligation, active transportation, and team sports. 
In their study of the "Correlation between physical activity and self-efficacy in Chinese university students", Hao and Xia (2017) found that self-efficacy plays an important role in influencing the Chinese university students to involve in physical activities. Self-efficacy refers to a person's belief in his/her ability to execute behaviors necessary to achieve desired outcomes. It is associated with many health behaviors such as smoking cessation and physical activity. It determines whether health behavior change will be initiated, how much effort will be expended, and how long it will be sustained in the face of obstacles and failures.

Alkhateeb, Alkhameesi, Lamfon (2019) stated that among the university students in Saudi Arabia, the most common barrier for not practicing exercise among the university students was time restrictions, accounting for $18.5 \%$ of all the reasons, followed by lack of motivation $(16.1 \%)$, unsuitable weather $(7.2 \%)$, and low income $(2.6 \%)$.

\subsection{Why this Research}

So far Taiwan region is concerned, there is no such known locally representative and internationally published research on this topic of facilitators and barriers which can keep students in or away from doing sports and physical activities. By finding out the these influencers which keep students in or away from doing these very beneficial physical activities through this present research, people, especially teachers, parents and concerned institutes and authorities in Taiwan region can understand better the importance of doing sports and physical activities, and can encourage students to do exercise, sports and physical activities regularly for their physical and mental health, moral behavior, academic performance, and help overall personality development in Taiwan region. This research also will open the door wide for future researchers.

\section{Method}

The present research is a quantitative, descriptive cross-sectional study. The present research used a self-designed survey questionnaire consisting of 9 questions with multiple-choice answers. With permission from the classroom teachers, the 9 multiplechoice paper questionnaires was distributed among the surveyed students. To investigate the perceived facilitators and barriers to physical activities, the present research focused on collected statistical data from students during the months of April to October, 2021, which can fairly represent the students' population in Taiwan, especially high school and college students. Once the students finished marking their answers, the questionnaires were collected and entered in the Microsoft Excel software for further study.

For data analysis, Microsoft Excel Pivot table was utilized. Through Microsoft Excel, the entered raw data was coded and converted into statistical numbers. Using the Microsoft Excel Pivot table, the converted statistical numbers were then transformed to pie chart and put to table for clear display of the results of frequency of distribution and 
percentage. The following table shows the 9 self-designed multiple-choice paper survey questionnaire.

Table 1: 9 questions with multiple-choice answers

\begin{tabular}{|c|c|c|c|c|}
\hline Multiple-choice questions & $\begin{array}{c}\text { Answer } \\
\text { A } \\
\end{array}$ & $\begin{array}{c}\text { Answer } \\
\text { B } \\
\end{array}$ & $\begin{array}{c}\text { Answer } \\
\text { C }\end{array}$ & $\begin{array}{c}\text { Answer } \\
\text { D } \\
\end{array}$ \\
\hline $\begin{array}{l}\text { 1. Do you do exercise or sports? } \\
\text { If yes, how many times a week? }\end{array}$ & A) 1 time & B) 2 times & C) 3 times & $\begin{array}{c}\text { D) More } \\
\text { than } 3 \text { times }\end{array}$ \\
\hline $\begin{array}{l}\text { 2. If you don't like exercise or } \\
\text { sports, then please give } \\
\text { reason/s. }\end{array}$ & $\begin{array}{l}\text { A) Not } \\
\text { interested }\end{array}$ & $\begin{array}{l}\text { B) I'm not good } \\
\text { at sports }\end{array}$ & $\begin{array}{l}\text { C) I don't } \\
\text { need it }\end{array}$ & D) Others \\
\hline $\begin{array}{l}\text { 3. If you do exercise or sports, } \\
\text { then please give reasons. }\end{array}$ & $\begin{array}{l}\text { A) Health and } \\
\text { fitness }\end{array}$ & $\begin{array}{l}\text { B) Friends and } \\
\text { family }\end{array}$ & C) Interest & $\begin{array}{l}\text { D) Give other } \\
\text { reasons }\end{array}$ \\
\hline $\begin{array}{l}\text { 4. If you don't do exercise or } \\
\text { sports, then please give } \\
\text { reasons? }\end{array}$ & $\begin{array}{l}\text { A) School and } \\
\text { study works }\end{array}$ & $\begin{array}{l}\text { B) Family } \\
\text { chore }\end{array}$ & $\begin{array}{l}\text { C) Part-time } \\
\text { job }\end{array}$ & $\begin{array}{l}\text { D) Other } \\
\text { reason/s }\end{array}$ \\
\hline $\begin{array}{l}\text { 5. Do you think your school } \\
\text { provides enough PE classes } \\
\text { for your health and fitness? }\end{array}$ & A) Yes & B) $\mathrm{No}$ & C) Maybe & $\begin{array}{l}\text { D) I have } \\
\text { no idea }\end{array}$ \\
\hline $\begin{array}{l}\text { 6. Do your parents encourage } \\
\text { you to do sports or exercise? }\end{array}$ & A) Yes & B) $\mathrm{No}$ & C) Sometimes & $\begin{array}{l}\text { They don't } \\
\text { care. }\end{array}$ \\
\hline $\begin{array}{l}\text { 7. Do your school teachers } \\
\text { encourage you to do sports or } \\
\text { exercise? }\end{array}$ & A) Yes & B) $\mathrm{No}$ & C) Sometimes & $\begin{array}{l}\text { They don't } \\
\text { care. }\end{array}$ \\
\hline $\begin{array}{l}\text { 8. Do you think doing regular } \\
\text { exercise or sports can help you } \\
\text { to do better in you study? }\end{array}$ & A) Yes & B) $\mathrm{No}$ & C) Maybe & $\begin{array}{l}\text { D) I have } \\
\text { no idea }\end{array}$ \\
\hline $\begin{array}{l}\text { 9. Do you think doing regular } \\
\text { exercise or sports can keep } \\
\text { your mind and body healthy? }\end{array}$ & A) Yes & B) $\mathrm{No}$ & C) Maybe & $\begin{array}{l}\text { D) I have } \\
\text { no idea }\end{array}$ \\
\hline
\end{tabular}

\subsection{Participants}

199 high school and College students from Hungkuo Delin University of Technology, Nan Chiang Vocational Senior High School, and Qingshui High School in New Taipei City, Taiwan joined the survey. Though 199 student sample was not a big sample and they were studying in New Taipei City, they pretty fairly represented the student community of Taiwan as they were from different parts of Taiwan. These students belonged in the age group of 15 to 25 who were studying in different grades.

\section{Results}

The following Table 2 shows each of the 9 questions used during the survey which were analyzed using Microsoft Excel Pivot Table. 
Table 2: Results of the 9 questions with multiple-choice answers

\begin{tabular}{|c|c|c|c|c|c|}
\hline Multiple-choice questions & $\begin{array}{c}\text { Answer } \\
\text { A }\end{array}$ & $\begin{array}{c}\text { Answer } \\
\text { B }\end{array}$ & $\begin{array}{c}\text { Answer } \\
\text { C }\end{array}$ & $\begin{array}{c}\text { Answer } \\
\text { D }\end{array}$ & $\begin{array}{c}\text { No } \\
\text { response }\end{array}$ \\
\hline $\begin{array}{l}\text { 1. Do you do exercise or sports? } \\
\text { If yes, how many times a week? }\end{array}$ & $\begin{array}{l}\text { A) } 1 \text { time } \\
58(29 \%)\end{array}$ & $\begin{array}{l}\text { B) } 2 \text { times } \\
55(28 \%)\end{array}$ & $\begin{array}{l}\text { C) } 3 \text { times } \\
24(12 \%)\end{array}$ & $\begin{array}{c}\text { D) More } \\
\text { than } 3 \text { times } \\
56(28 \%)\end{array}$ & $\begin{array}{c}6 \\
(3 \%)\end{array}$ \\
\hline $\begin{array}{l}\text { 2. If you don't like exercise or } \\
\text { sports, then please give reason/s. }\end{array}$ & $\begin{array}{c}\text { A) Not } \\
\text { interested } \\
57(29 \%)\end{array}$ & $\begin{array}{l}\text { B) I'm not good } \\
\text { at sports } \\
49(25 \%)\end{array}$ & $\begin{array}{l}\text { C) I don't } \\
\text { need it } \\
14(7 \%)\end{array}$ & $\begin{array}{l}\text { D) Others } \\
33(16 \%)\end{array}$ & $\begin{array}{c}46 \\
(26 \%)\end{array}$ \\
\hline $\begin{array}{l}\text { 3. If you do exercise or sports, } \\
\text { then please give reasons. }\end{array}$ & $\begin{array}{l}\text { A) Health and } \\
\text { fitness } \\
58(29 \%)\end{array}$ & $\begin{array}{l}\text { B) Friends and } \\
\text { family } \\
55(28 \%)\end{array}$ & $\begin{array}{l}\text { C) Interest } \\
24(12 \%)\end{array}$ & $\begin{array}{c}\text { D) Give } \\
\text { other reasons } \\
56(28 \%) \\
\end{array}$ & $\begin{array}{c}6 \\
(3 \%)\end{array}$ \\
\hline $\begin{array}{l}\text { 4. If you don't do exercise } \\
\text { or sports, then please give } \\
\text { reasons? }\end{array}$ & $\begin{array}{l}\text { A) School and } \\
\text { study works } \\
73(37 \%)\end{array}$ & $\begin{array}{l}\text { B) Family } \\
\text { chore } \\
26(13 \%)\end{array}$ & $\begin{array}{l}\text { C) Part-time } \\
\text { job } \\
39(20 \%)\end{array}$ & $\begin{array}{l}\text { D) Other } \\
\text { reason/s } \\
36(18 \%)\end{array}$ & $\begin{array}{c}25 \\
(12 \%)\end{array}$ \\
\hline $\begin{array}{l}\text { 5. Do you think your school } \\
\text { provides enough PE classes for } \\
\text { your health and fitness? }\end{array}$ & $\begin{array}{l}\text { A) Yes } \\
67(34 \%)\end{array}$ & $\begin{array}{c}\text { B) No } \\
41(21 \%)\end{array}$ & $\begin{array}{l}\text { C) Maybe } \\
70(35 \%)\end{array}$ & $\begin{array}{c}\text { D) I have } \\
\text { no idea } \\
20(10 \%) \\
\end{array}$ & $\begin{array}{c}1 \\
(0 \%)\end{array}$ \\
\hline $\begin{array}{l}\text { 6. Do your parents encourage } \\
\text { you to do sports or exercise? }\end{array}$ & $\begin{array}{c}\text { A) Yes } \\
89(45 \%) \\
\end{array}$ & $\begin{array}{c}\text { B) No } \\
29(14 \%) \\
\end{array}$ & $\begin{array}{l}\text { C) Sometimes } \\
49(25 \%)\end{array}$ & $\begin{array}{c}\text { They don't } \\
\text { care } 32(16 \%)\end{array}$ & \\
\hline $\begin{array}{l}\text { 7. Do your school teachers } \\
\text { encourage you to do sports } \\
\text { or exercise? }\end{array}$ & $\begin{array}{l}\text { A) Yes } \\
100(50 \%)\end{array}$ & $\begin{array}{c}\text { B) No } \\
37(19 \%)\end{array}$ & $\begin{array}{l}\text { C) Sometimes } \\
40(20 \%)\end{array}$ & $\begin{array}{c}\text { They don't } \\
\text { care } \\
22(11 \%)\end{array}$ & \\
\hline $\begin{array}{l}\text { 8. Do you think doing regular } \\
\text { exercise or sports can help you } \\
\text { to do better in your study? }\end{array}$ & $\begin{array}{c}\text { A) Yes } \\
90(45 \%)\end{array}$ & $\begin{array}{c}\text { B) No } \\
13(7 \%)\end{array}$ & $\begin{array}{l}\text { C) Maybe } \\
75(38 \%)\end{array}$ & $\begin{array}{l}\text { D) I have } \\
\text { no idea } \\
20(10 \%)\end{array}$ & $\begin{array}{c}1 \\
(0 \%)\end{array}$ \\
\hline $\begin{array}{l}\text { 9. Do you think doing regular } \\
\text { exercise or sports can keep your } \\
\text { mind and body healthy? }\end{array}$ & $\begin{array}{c}\text { A) Yes } \\
163(82 \%)\end{array}$ & $\begin{array}{l}\text { B) No } \\
3(1 \%)\end{array}$ & $\begin{array}{l}\text { C) Maybe } \\
26(13 \%)\end{array}$ & $\begin{array}{l}\text { D) I have } \\
\text { no idea } \\
7(4 \%)\end{array}$ & \\
\hline
\end{tabular}

\section{Discussion}

In the last 60 years or so, many scholars, experts in the field of education, sports and psychology have done many researches about the benefits sports and physical activities offer to student community. But today, more and more students are found staying away from sports and physical activities, thus keeping student community unhealthy and unfit. The main purpose of the present research is to find out the perceived benefits and barriers which are responsible for keeping in or away Taiwanese students from doing sports and physical activities.

Question 1: Do you do exercise or sports? If yes, how many times a week?
A) 1 time,
B) 2 times,
C) 3 times,
D) More than 3 times. 
Figure 1: Frequency of exercise per week

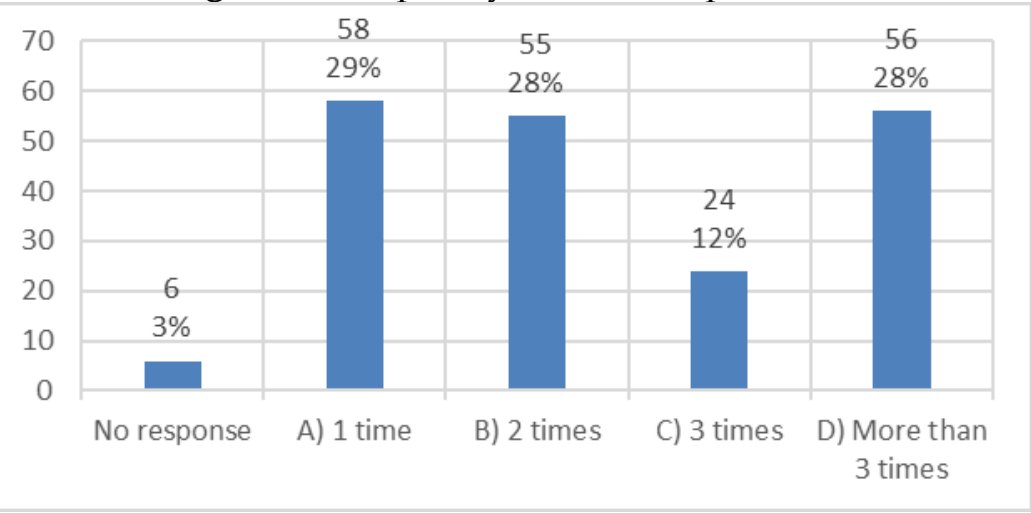

Figure 1 of question 1 shows that out of total 199 adolescent and college students, $56(28 \%)$ students do enough exercise, at least the number of sessions is concerned. The remaining 143 (72\%) students either don't do, do little, or do not meet the 60 minutes per day of moderate-to-vigorous intensity physical activities for adolescents and at least 150300 minutes of moderate-intensity aerobic physical activity, or at least 75-150 minutes of vigorous-intensity aerobic physical activity recommended by the World Health Organization.

Question 2: If you don't like exercise or sports, then please give reason/s.
A) Not interested,
B) I am not good at sports,
C) I don't need it,
D) Give other reason ----

Figure 2: Reasons for not doing exercise/sports

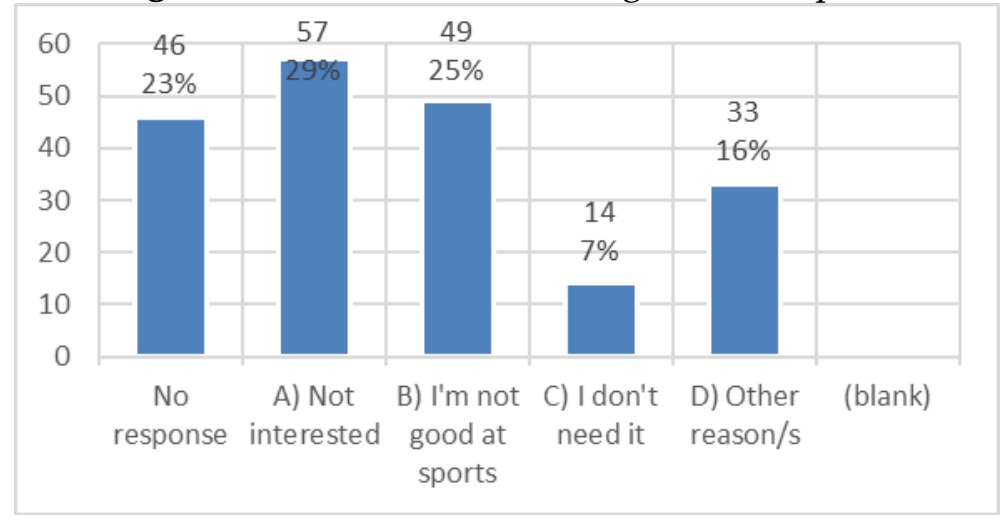

Figure 2 shows why students don't involve in regular sports, exercise or any physical activities. Out of 199 students, 57 (29\%) students chose "Not interested" as the first internal barrier. This was followed by the second internal barrier - "I am not good at sports" with 49 (25\%) students. It means "interest" plays a big role. 
Question 3: If you do exercise or sports, please give reason/s why?
A) Health and fitness,
B) friends \& family members,
C) interest,
D) Give other reason

Figure 3: Reasons for doing exercise/sports

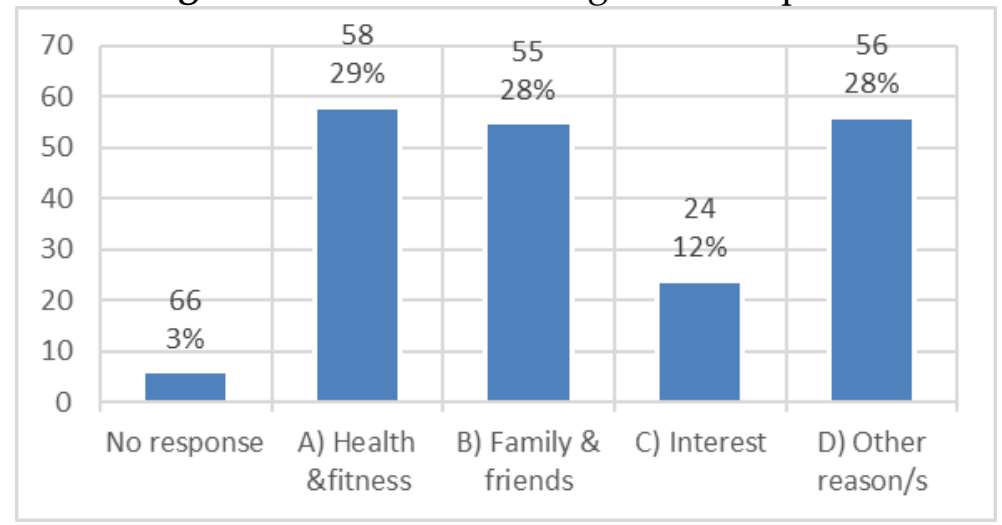

On the other hand, Figure 3 shows interest is the least choice students made on why students do sports or physical activities. Out of 199, only 24 (12\%) of them do because of "interest" while 55 students $(28 \%)$ chose "health and fitness" and another 58 (29\%) opted "family and friends" as the reasons why they do sports and physical activities.

Question 4: If you don't do regular sports or exercise, then what keeps you away from doing exercise or sports?
A) School and study works,
B) family chores,
C) part time job,
D) Other reason/s.

Figure 4: External factors for not doing exercise/sports

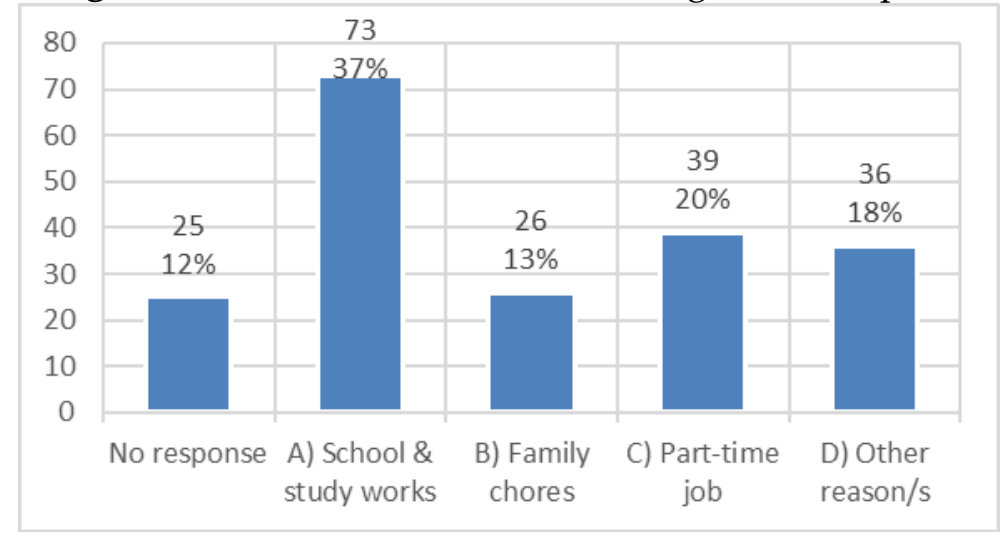


In Figure 4, among the external barriers, "School \& study works" is the highest students opted. Out of 199 students, 73 (37\%) chose school and study works as the biggest factor which keep them away from sports or physical activities. It is followed by "Parttime jobs" with 39 (20\%) students. Only 26 (13\%) chose "family chores" as the external barrier which keep them away from sports and physical activities. So, concerned authorities need to discuss if students are kept too busy on study sacrificing their health.

Question 5: Do you think your school provides enough PE classes for your health and fitness?
A) Yes,
B) No,
C) Maybe,
D) I have no any idea.

From Figure 5, it can be seen that out of 199 students only 41 (21\%) of them think the given physical education classes ( 2 periods) are not enough for health and fitness. The remaining 151 (79\%) of the students are not even aware of how much time they need to spend on physical or sports activities to stay healthy and fit. In their study, Ching-Lin $\mathrm{Wu}$ and Chen-Kang Chang (2019) reported that only $12.1 \%$ of $15-18$ year-olds (19.4\% of boys and $5.8 \%$ of girls) met the World Health Organization standard of at least 60 min of moderate to vigorous physical activity per day followed by more alarming result with only $5.4 \%$ younger children of $13-15$ year-olds ( $8.7 \%$ of boys and $1.9 \%$ of girls) meeting the WHO standard. In addition, only $5.8 \%$ of $7-12$ year-old boys and $2.8 \%$ of girls participated in moderate physical activity more than 4 times a week. It clearly indicates that children and youth in Taiwan are not receiving sufficient levels of physical activity in schools.

Figure 5: Opinions on the frequency of PE classes

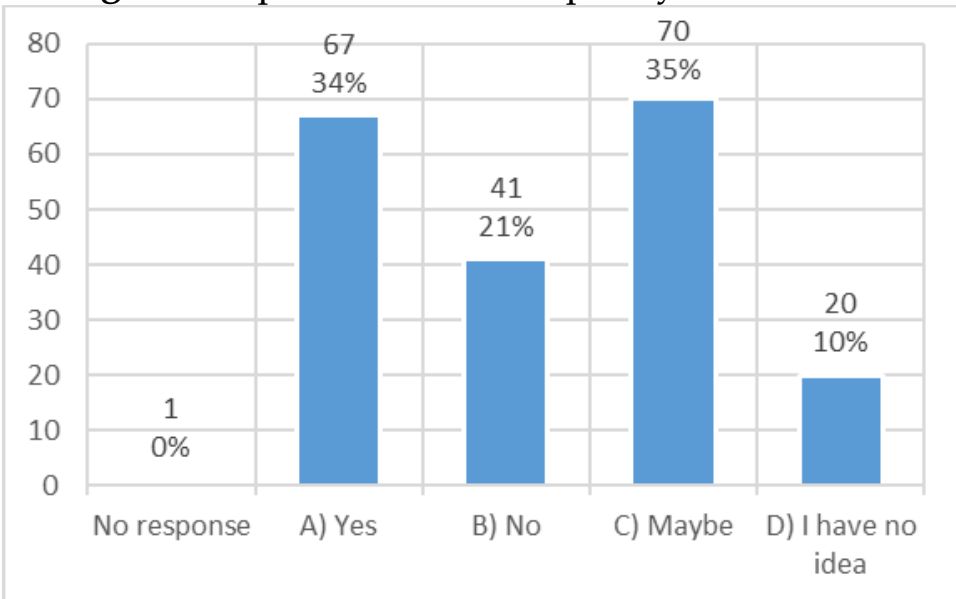

Question 6: Do your parents encourage you to do sports or exercise? A) Yes, 

B) No,
C) Sometimes,
D) They don't care.

Figure 6: Parents' role on doing exercise/sports

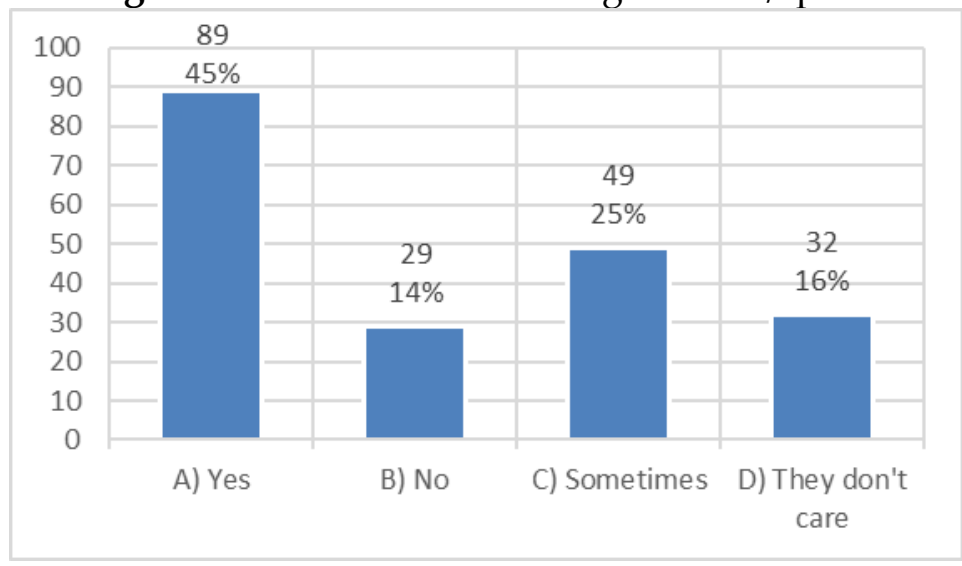

From the result of question 6 in Figure 6, it can be seen that social support also plays a very important role in deciding whether adolescent students would involve or not in sports or physical activities. From the column chart, it can be clearly seen that out of 199 students 89 (45\%) of them chose "Yes" while 49 (25\%) chose "Sometimes" 32 (16\%) "They don't care" and 29 (14\%) chose "No" respectively. From the figure, it looks like more parents encourage their children do sports and physical activities. But the truth is that the remaining 110 (55\%) of parents don't encourage their children to do these healthy activities. Even the $45 \%$ of parents' encouragement doesn't ensure their children would do these physical activities. Thus, this figure shows that social support, especially from parents play a very important role in helping students in doing sports and physical activities.

Question 7: Do your school teachers encourage you to do sports or exercise?
A) Yes,
B) No,
C) Sometimes,
D) They don't care.

Next to parents, teachers also play a very big role in encouraging students to do sports and physical activities. As can be seen from pie chart in figure 7, the support students get from teachers is pretty good with 100 (50\%) out of 199 students chose the answer "Yes". It means another 50\% of teachers don't give enough support to their students, thus leading adolescent and college students stay away from such good habits. 
Figure 7: Teachers' role on doing exercise or sports

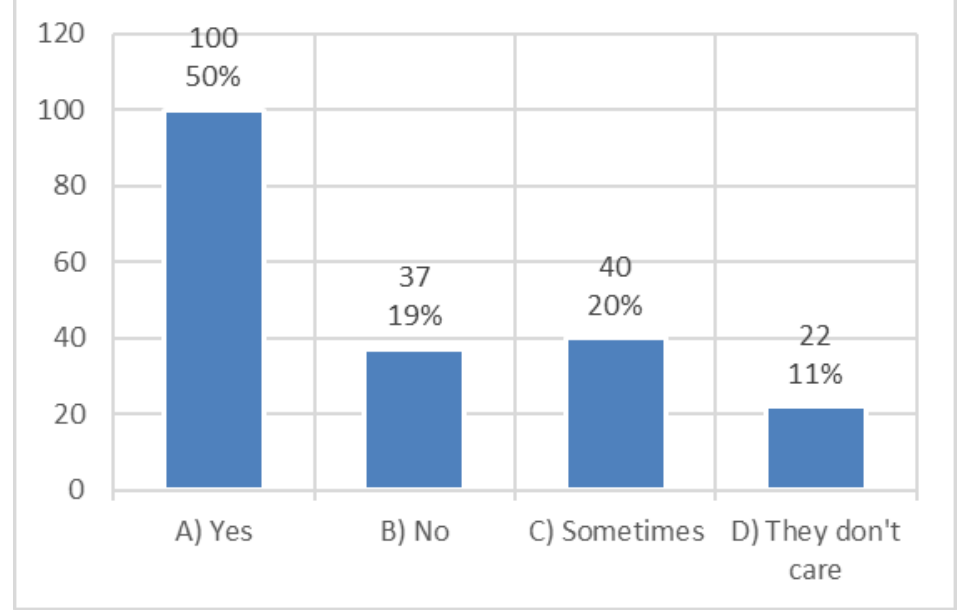

Question 8: Do you think doing regular exercise or sports can help you to do better in your study?
A) Yes,
B) No,
C) Maybe,
D) I have no idea.

Figure 8: Students' opinion on regular exercise/sports

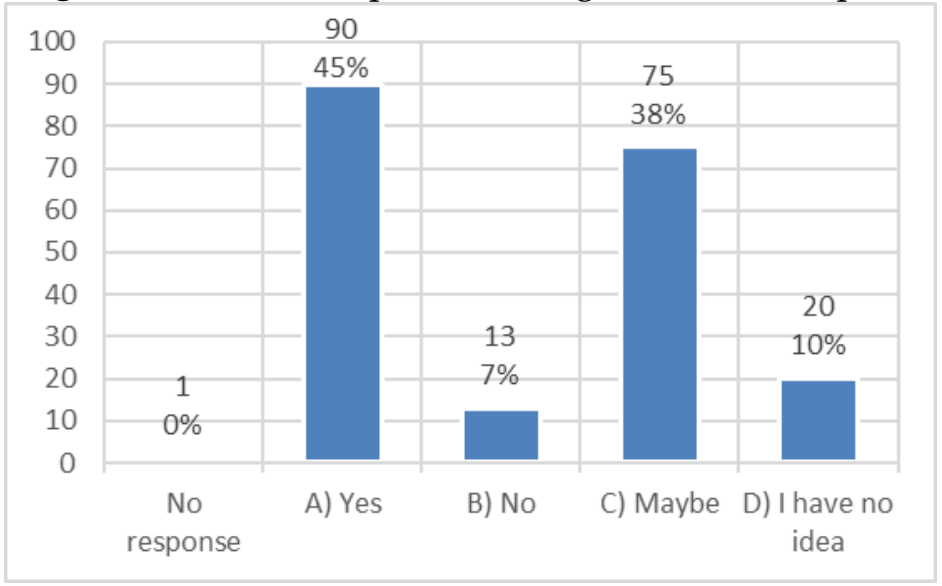

In question 8 , "Do you think doing regular exercise or sports can help you to do better in your study?", 45\% of students answered "Yes" while 55\% of them were not sure if sports and physical activities can help them in their academic performance.

Question 9: Do you think doing regular exercise and sports can keep your mind and body healthy?
A) Yes,
B) No,
C) Maybe,
D) I have no idea. 
Figure 9: Students' opinions of exercise/sports on mental/physical health

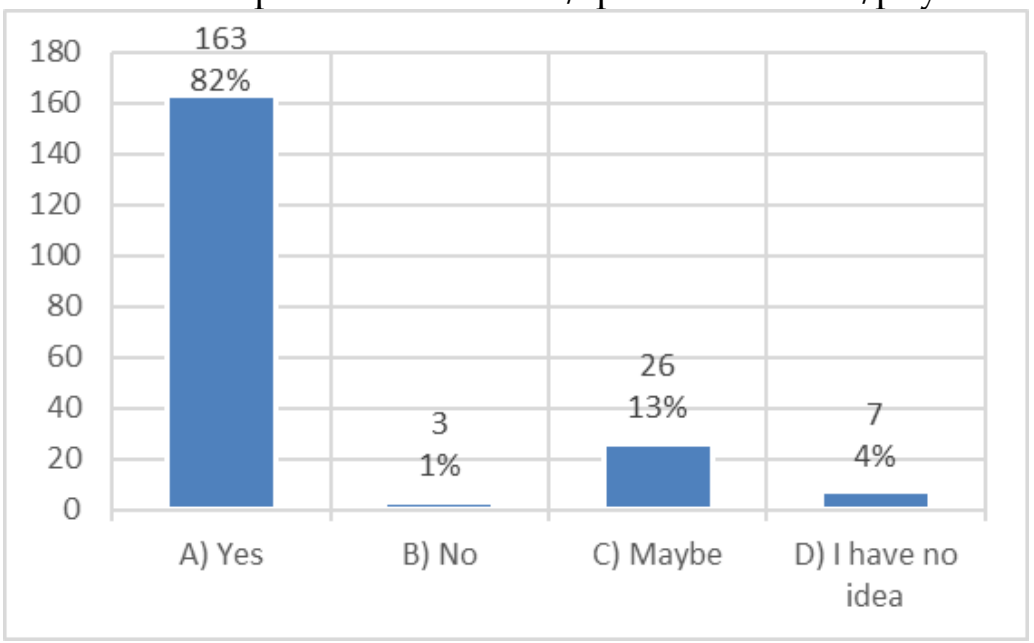

From the last Figure 9 of question 9, one very interesting fact comes out. Out of total 199 students, 163 (82\%) students know that doing regular sports or physical activities can keep them healthy physically and mentally. 26 (13\%) students chose "Maybe", 7 (4\%) "I have no idea" and only $3(1 \%)$ students chose "No) respectively. It means most of the students (82\%) know and agree that doing sports and physical activities can keep them healthy physically and mentally, but only $28 \%$ of them spend enough time on sports or physical activities per week. It means they need encouragement. Boiché and Sarrazin (2009) found that parental support and the value parents' grant to sport were positively associated with children's sport participation. So do with teachers. When parents place increasingly greater importance on physical-sport practice, the likelihood of their children being physically inactive is greatly reduced (2012). From figures 2 and 3, it is also clear that external factors influenced student community more than internal factors.

From this study, it can be concluded that among the important factors which keep students in or away from doing sports and physical activities are: too much school works, part-time jobs, and not enough social encouragements, lack of interest, no self-confidence in sports, and lack of knowledge respectively.

\section{Limitations of the study}

Although this is a quantitative, cross-sectional study among Taiwan students, the data was collected only from 199 high school and college students as well as only from 3 institutes in New Taipei City. Elementary and university students were not covered. Also, some more questions can be added, and the present self-designed questions can be modified if necessary. The result would be even more complete, accurate, and reliable if the sample data were collected in a large scale from different educational institutes from around Taiwan. 


\section{Conclusion}

In spite of all the benefits sports and physical activities offer, the rate and number of students involving in sports and physical activities is declining significantly day by day. The present study investigated the influencers - facilitators and barriers that keep in or away Taiwanese adolescent and college students from doing sports and physical activities. The present study found that the main responsible factors which helped Taiwanese students to involve in exercise, sports or physical activities were: interest and social supports, especially from parents and teachers. On the other hand, too busy on school works, part-time jobs, not enough social support and encouragements, lack of interest, no self-confidence in sports, and lack of knowledge respectively were the barriers. Another factor was too little time given on physical education classes. One very interesting finding was that, though most of the students (82\%) knew that doing sports and physical activities could keep them physically and mentally healthy, only $28 \%$ of them spent enough time on doing sports or physical activities per week. It means the remaining more than $70 \%$ of student community live in sedentary lifestyle. So, it is time for the concerned authorities, parents and teachers to take this matter seriously, and encourage and support student community to keep the good habit of doing sports and physical activities regularly for their health, fitness, academic performance, and for an overall development.

\section{Conflict of Interest Statement}

The author has no conflict of interest to disclose/declare.

\section{About the Authors}

Dr. Ngangbam Shantikumar Meetei/Chen Jung-Sheng ( $\mathrm{PhD}$ in Linguistics), Senior Assistant Professor of English at Hungkuo Delin University (Taiwan), Professional natural athlete and winner of Professional Natural Olympia Bodybuilding Championships, Natural Bodybuilding Hall of Famer, President of INBA ASIA, INBA Taiwan (International Natural Bodybuilding Association).

\section{References}

Alkhateeb, S. A., Alkhameesi, N. F., Lamfon, G. N. (2019). Pattern of physical exercise practice among university students in the Kingdom of Saudi Arabia (before beginning and during college): a cross-sectional study. BMC Public Health 19, 1716. https://doi.org/10.1186/s12889-019-8093-2.

Andersen, M. P., Starkopf, L., Sessa, M., Mortensen, R. N., Vardinghus-Nielsen, H., Bøggild, H., Lange, T., \& Torp-Pedersen, C. (2017). The indirect and direct pathways between physical fitness and academic achievement on commencement 
in post-compulsory education in a historical cohort of Danish school youth. BMC public health, 17(1), 699. https://doi.org/10.1186/s12889-017-4712-y

Eva Sanz-Arazuri, Ana Ponce-de-León-Elizondo, and María Ángeles Valdemoros-SanEmeterio (2012). Parental Predictors of Physical Inactivity in Spanish Adolescents. Journal of Sports Science and Medicine. https://www.ncbi.nlm.nih.gov/pmc/articles/PMC3737854/

Arzu, D., Tuzun, E. H., \& Eker, L. (2006). Perceived barriers to physical activity in university students. Journal of sports science \& medicine, 5(4), 615-620. https://www.ncbi.nlm.nih.gov/pmc/articles/PMC3861763

Awadalla N. J., Aboelyazed A. E., Hassanein M. A., Khalil S. N., Aftab R., Gaballa I. I., Mahfouz A. A. (2014, Oct.) Assessment of physical inactivity and perceived barriers to physical activity among health college students, south-western Saudi Arabia. East Mediterr Health J. 2014 Oct 20;20 (10):596-604. PMID: 25356690. https://pubmed.ncbi.nlm.nih.gov/25356690

Boiché J. S. C., Sarrazin P. G. (2009). Proximal and distal factors associated with dropout versus maintained participation in organized sport. Journal of Sports Science and Medicine 8(1), 9-16. https://www.ncbi.nlm.nih.gov/pmc/articles/PMC3737782

Ching-Lin Wu and Chen-Kang Cha (2019). Results from the Chinese Taipei (Taiwan) 2018 Report Card on physical activity for children and youth. Journal of Exercise Science \& Fitness 17 (2019) 8e13. http://creativecommons.org/licenses/by-nc$\underline{\mathrm{nd} / 4.0 /}$

Christine A. Crumbley, Tracey A. Ledoux, Craig A. Johnston (2019, 14 October). Physical Activity During Early Childhood: The Importance of Parental Modeling. Journal article. https://journals.sagepub.com/doi/full/10.1177/1559827619880513

Donnelly, J. E., Hillman, C. H., Castelli, D., Etnier, J. L., Lee, S., Tomporowski, P., Lambourne, K., \& Szabo-Reed, A. N. (2016). Physical Activity, Fitness, Cognitive Function, and Academic Achievement in Children: A Systematic Review. Medicine and science in sports and exercise, 48(6), 1197-1222. https://doi.org/10.1249/MSS.0000000000000901.

Kenneth R. Allison, Edward M. Adlaf, John J. M. Dwyer, Daria C. Lysy, Hyacinth M. Irving, M. (2007, March). The Decline in Physical Activity among Adolescent Students a Cross-national Comparison. Canadian journal of public health. https://www.researchgate.net/publication/6386223

Kevi McCoy (2020). Influences and Perceptions of Exercise and Physical Activity among Taiwanese and non-Taiwanese Adults. (Master's Thesis). National Chengchi University,

Taiwan. https://nccur.lib.nccu.edu.tw/bitstream/140.119/131386/1/600601.pdf

Kyan, A., Takakura, M., \& Miyagi, M. (2018). Does Physical Fitness Affect Academic Achievement among Japanese Adolescents? A Hybrid Approach for Decomposing Within-Person and Between-Persons Effects. International journal of environmental research and public health, 15(9), 1901. https://doi.org/10.3390/ijerph15091901 
Liu, Hao; Dai, Xia (2017). Correlation between physical activity and self-efficacy in Chinese university students, Department of Physical Education. Journal of Sport Psychology 2017, Vol 26, Suppl 4, pp. 110-114. https://ddd.uab.cat/pub/revpsidep/revpsidep a2017v26sup4/revpsidep a2017v2 6n6p110.pdf.

Lopez, C. Q., Vera, V. D. G., Lopez, Álzate Jaramillo, Carolina, J., C. (2020). Impact of sport on social cognition: an analysis based on structural equational models. Journal of Physical Education and Sport $\AA$ (JPES), Vol.20 (1), Art 4, pp. 31 - 36, 2020 online ISSN: 2247 - 806X; p-ISSN: 2247 - 8051; ISSN - L = 2247 - 8051 @ JPES.

Manuel Gómez-López, Antonio Granero Gallegos and Antonio Baena Extremera. (2010, 10 September). Perceived Barriers by University Students in the Practice of Physical Activities, (OJournal of Sports Science and Medicine. Journal article. Faculty of Sports Science, University of Murcia, Murcia, Spain. https://www.researchgate.net/publication/258035654

Gorton, Michael J. (2010). Exploring the Impact of Sports Participation on Academic Achievement in a Middle School. (Master's thesis). The College at Brockport, New York

https://digitalcommons.brockport.edu/cgi/viewcontent.cgi?article=1039\&context= edc theses

Michael, S. L., Merlo, C. L., Basch, C. E., Wentzel, K. R., \& Wechsler, H. (2015). Critical connections: health and academics. The Journal of school health, 85(11), 740-758. https://doi.org/10.1111/josh.12309

Mohammad Younis K., Dr Asif J., Dr Umar A. K., Uzma K. (2012). Association between Participation in Sports and Academic Achievement of College Students. International Journal of Academic Research in Business and Social Sciences. https://pdf4pro.com/view/association-between-participation-in-sports-andacademic-5775f5.html

Ngangbam, Shantikumar Meetei (2020, not published yet). The Impact of Regular Exercise or Sports Participation on Student's Academic Performance. Paper presented at 59th International Conference on Business, Education, Social Science, and management (BESM-59). Taipei, Taiwan.

R. M. Youssef, K. Al Shafie, M. Al-Mukhaini and H. Al-Balushi (2013). Physical activity and perceived barriers among high-school students in Muscat, Oman. Journal article. https://www.researchgate.net/publication/259209466

Rodolfo Iván Martínez-Lemos, Anna María Puig-Ribera, Oscar García-García (2014) Perceived Barriers to Physical Activity and Related Factors in Spanish University Students. Open Journal of Preventive Medicine, 4, 164-174. http://dx.doi.org/10.4236/ojpm.2014.44022

Sanz-Arazuri E., Ponce-de-León-Elizondo A., Valdemoros-San-Emeterio M. A. (2012). Parental predictors of physical inactivity in Spanish adolescents. Journal of Sports Science and Medicine 11. https://www.ncbi.nlm.nih.gov/pmc/articles/PMC3737854 
Smetaniuk, T., Johnson, D., Creurer, J., Block, K., Schlegel, M., Butcher, S., \& Oosman, S. N. (2017). Physical Activity and Sedentary Behaviour of Master of Physical Therapy Students: An Exploratory Study of Facilitators and Barriers. Physiotherapy Canada. Physiotherapie Canada, 69(3), 260-270. https://doi.org/10.3138/ptc.2015-76EP

Tomporowski, P. D., Davis, C. L., Miller, P. H., \& Naglieri, J. A. (2008). Exercise and Children's Intelligence, Cognition, and Academic Achievement. Educational psychology review, 20(2), 111-131. https://www.ncbi.nlm.nih.gov/pmc/articles/PMC2748863/

Vasilopoulos, F., \& Ellefson, M. R. (2021). Investigation of the associations between physical activity, self-regulation and educational outcomes in childhood. PloS one, 16(5), e0250984. https://doi.org/10.1371/journal.pone.0250984

Vibha V. Prasad (2012). Students and Sports: The Participation of Sports and Academic Achievement. (Master's thesis). Massey University, College of Education, Albany, New

Zealand. https://mro.massey.ac.nz/bitstream/handle/10179/3352/02 whole.pdf?sequence $=4$ \&isAllowed $=y$

World Health Organization. (2019, 22 November). The Lancet Child \& Adolescent Health https://www.who.int/news/item/22-11-2019

Zhang, Y., Ma, X., Zhao, J., Shen, H., \& Jiang, F. (2019). The Effect of Strengthened Physical Education on Academic Achievements in High School Students: A QuasiExperiment in China. International journal of environmental research and public health, 16(23), 4688. https://doi.org/10.3390/ijerph16234688 
Ngangbam, Shantikumar Meetei; Chen Jung-Sheng

PERCEIVED FACTORS KEEPING STUDENTS IN OR AWAY FROM

DOING SPORTS AND PHYSICAL ACTIVITIES IN TAIWAN REGION

Creative Commons licensing terms

Authors will retain the copyright of their published articles agreeing that a Creative Commons Attribution 4.0 International License (CC BY 4.0) terms will be applied to their work. Under the terms of this license, no permission is required from the author(s) or publisher for members of the community to copy, distribute, transmit or adapt the article content, providing a proper, prominent and unambiguous attribution to the authors in a manner that makes clear that the materials are being reused under permission of a Creative Commons License. Views, opinions and conclusions expressed in this research article are views, opinions and conclusions of the author(s). Open Access Publishing Group and European Journal of Physical Education and Sport Science shall not be responsible or answerable for any loss, damage or liability caused in relation to/arising out of conflict of interests, copyright violations and inappropriate or inaccurate use of any kind content related or integrated on the research work. All the published works are meeting the Open Access Publishing requirements and can be freely accessed, shared, modified, distributed and used in educational, commercial and non-commercial purposes under a Creative Commons attribution 4.0 International License (CC BY 4.0). 